\title{
A Descriptive Study of Thailand's ESP Programs: Policy Implications for AEC
}

\author{
Kantatip Sinhaneti, Wei Fu \\ Shinawatra University, Thailand \\ weiweimy1234@hotmail.com
}

\begin{abstract}
As a country member, Thailand needs to prepare for the upcoming AEC. One way to look at how the country has prepared for this is to look at the ESP programs offered in universities, both public and private, especially ESP programs in preparation for the eight careers: engineering, hospitality \& tourism, architecture, dentistry, medical practices, accounting, surveying, nursing. This study therefore explores the AEC careers offered in public and private universities. This was a descriptive study. The international programs under study fell into two levels: Bachelor (335 programs) and Master (436 programs). The results of descriptive analysis revealed these findings. On the eight AEC careers, three most popular programs offered in Thailand included hospitality \& tourism, engineering and accounting respectively. On the other hand, no land surveying programs are offered at both levels; no dentistry programs at Bachelor level; no medical practice is offered at Master level. For policy implication, Thailand should offer these programs in the future.
\end{abstract}

Keywords: A descriptive study, Thailand's ESP programs, policy implications for AEC

\section{Introduction}

The Association of Southeast Asian Nations signed an aspiring agreement in 2007 to build ASEAN Economic Community (AEC) to be "One Vision, One Identity, One Community." The ability and willingness of learning and utilizing new knowledge and technologies are essential to rise up a nation competitiveness, productivity and economy. Today especially, ASEAN countries need intelligent workers more than ever before; whereas they do not have educational systems capable of producing the workforces that are required. In order to improve professional qualifications and skills from 2005 to 2012, ASEAN Member signed Mutual Recognition Arrangement (MRA) to offer 8 standard occupations, which are medical practice (doctor), dentistry, nursing, engineering, accounting, architecture, surveying and hospitality \& tourism. Thailand has positioned itself as a hub of higher education in the Southeast Asian countries and aims to develop the quality of higher education that meets international standards in order to strengthen major manpower and enable to compete with the other countries.

\section{Literature Review}

Thailand has been established of a modern system of higher education for nearly 100 years. In 1917, the first university, Chulalongkorn University, was found in Thailand. In 1934, Thammasart University was established with the aim of educating a large number of people in the moral and political sciences. In 1960, Thailand introduced a five-year National Development Plan after having learned from the United States of American, through the United States Agency for International Development Program. The history of Thailand international education can date back to the 17th century, in which the first foreign school was, opened (CharasSuwanwela, 2000). In 1990, Assumption Business Administration College (ABAC), the first international university, was opened to offer various programs. After joining the World Trade Organization (WTO) , Thailand has played a more active role in the regional and international markets. Due to the influence of technological advances, globalization, international trade, and investments, Thailand's higher education needs to help strengthen Thai human resources to face both international and global challenges (Chang, 2004). 
Table 1: The Number of international programs in Thailand during 2004-2012

\begin{tabular}{llllll}
\hline $\begin{array}{l}\text { Academic } \\
\text { year }\end{array}$ & $\begin{array}{l}\text { Number of International } \\
\text { Programs }\end{array}$ & $\begin{array}{l}\text { Bachelor } \\
\text { Degree }\end{array}$ & $\begin{array}{l}\text { Master } \\
\text { Degree }\end{array}$ & Doctoral & Others \\
\hline 2004 & 465 & 153 & 203 & 109 & 0 \\
2005 & 520 & 176 & 217 & 127 & 0 \\
2006 & 727 & 241 & 290 & 178 & 18 \\
2007 & 844 & 277 & 327 & 220 & 20 \\
2008 & 884 & 296 & 350 & 215 & 23 \\
2010 & 981 & 342 & 389 & 225 & 25 \\
2012 & 1,071 & 344 & 394 & 249 & 30 \\
\hline
\end{tabular}

The Office of the Higher Education Commission (2005-2014)

This table shows that the number of the international programs of both public and private universities in Thailand is rising annually. In 2004, there were only 465 international programs offered by Thai higher institutions. However, there were 1,071 programs taught in English at undergraduate and graduate levels in 2012. According to the Office of the Higher Education Commission (2009), "Curriculums offered were jointly designed by Thai and foreign counterpart high education institutions". During these years, the international education rapidly increased and attracted more Thai and foreign students join these programs. From the early 1960's English for Specific Purposes (ESP) has grown to become one of the most prominent areas of EFL teaching today. English for Specific Purposes is a movement based on the proposition that all language teaching should be tailored to the specific learning and language use needs for identified groups of students and also sensitive to the socio-cultural contexts in which these students will use English (Celce \& McIntosh, 1991).

Thailand, one of the first five foundation countries, including Republic of Indonesia, Malaysia, and Republic of the Philippines, Republic of Singapore, played a vital role in the establishment of the Association of Southeast Asian Nations on the $8^{\text {th }}$ of August 1967. Thailand's economy grew rapidly during these years (Schwab, 2010). Many workers have acquired competences on-the-job yet remained without qualifications. The lack of professional workforce is a big challenge for Thai to meet the coming AEC free labor market (UNESCO, 2014). A number of measures are envisaged to improve the quality of education and training in Thailand. These include improving the quality of content, inputs and standards, introducing assessment based on learning outcomes, and ensuring internal and external assessment of educational institutions at every qualification level (Choomnoom, 2011). The capacities of educational institutions and of public and private sector training providers to implement the Thai National Qualifications Framework (NQF) will be strengthened, making them better able to meet the needs of production and services. Training will also be introduced to raise the caliber of educational personnel (UNESCO, 2014).

Despite a number of challenges, the Thai government managed to formulate a 15 -year framework for the country's higher education, starting from 2008, Thailand's educational strategies to prepare to enter the ASEAN countries in terms of English proficiency, curriculum development, teaching with international quality standard. To assist the nation towards this goal, the Ministry of Education has mandated that the education sectors throughout the nation are to prepare their students for ASEAN Community 2015 (ASEAN Curriculum Sourcebook, 2012). As for the other ASEAN member countries, Cambodia, Indonesian, Lao PDR, Myanmar, Philippine, Vietnam, a major challenge will be to address the mismatch between the needs of the labor market in terms of skills, critical thinking ability and knowledge and the current products on the market (Juan, 2014). Being an ASEAN member, those countries enjoy a lot of benefits from larger market access and lower input and free regional mobility of skilled labor (Aring, 2015). To face those challenges, those ASEAN countries established a lot of national policies to enhance capacity of higher education, such as The Educational Management Information System Master Plan 2014-2018, Cambodia (Ministry of Education Youth and Sport, March 2014, p-ii); National Skill Development Authority (NSDA), Myanmar (Ministry of Labor, Employment and Social Security, 2014); Vietnam Education in the Early Years of the 21st Century (Do, 2013).

In Malaysia and Thailand, the governments believe that investing in graduate education contributes to national economic development (Chien \& Chapman, 2014). Malaysia, a Thai neighboring country, has also a 
national objective to become an educational hub in the region (Zaaba et al., 2011). Only Singapore and Brunei Darussalam have already achieved much in meeting AEC's goals. For Brunei Darussalam, ASEAN Secretariat marked the Sultanate's AEC Scorecard highly back in May 2012, with eight out of 19 categories already fully implemented and remainder more than half completed (The Ministry of Education Strategic Plan, 20122017). Borneo Bulletin Online (March 25, 2015) reported that Brunei Darussalam stands to reap the benefits of a structural business regulatory reform as it works toward the realization of the ASEAN Economic Community (AEC) by the year's end. For Singapore, the preparations are as follows: Increasing Cohort Participation Rates through increased spending, Enhancing Continuing Education and Training Landscape, Maintaining Affordability of Higher Education, Cross-Border Higher Education, ASEAN Credit Transfer System, Student Exchanges, Building up SEAMEO Research Clusters in the areas of Urban, Environment and Sustainability Issues, Health and Medical Issues, and Social Sciences. Singapore is also the best prepared for the AEC because the city-state is a free port that has never relied for long periods on tariffs and other economies depend heavily on tariff duties (The Nation, 2013).

Purposes of the Study and Research Questions: This paper is based on a study from 335 Bachelor international degree programs and 436 Master international degree programs both at public and private universities in Thailand, focusing on the programs that are supporting $8 \mathrm{AEC}$ careers. This paper aims to discover whether Thai higher education is ready for the full implementation of the ASEAN Economic Community at the end of 2015 or not. And the research questions are as follows:

- How many international ESP programs are supporting 8 AEC standard careers?

- What are the details of those programs offered by Thai institutions?

\section{Methodology}

This is a content analysis study. The researcher uses descriptive statistics as the instrument to analyze data. The data are presented by charts and diagrams. The findings of the study were grouped by using descriptive statistics into two categories: overview of Thai higher international education that supports 8 AEC careers, details of 8 AEC careers in both public and private universities in Thailand.

\section{Findings, discussion and conclusion}

This part presents the findings, discussions and a conclusion of the study.

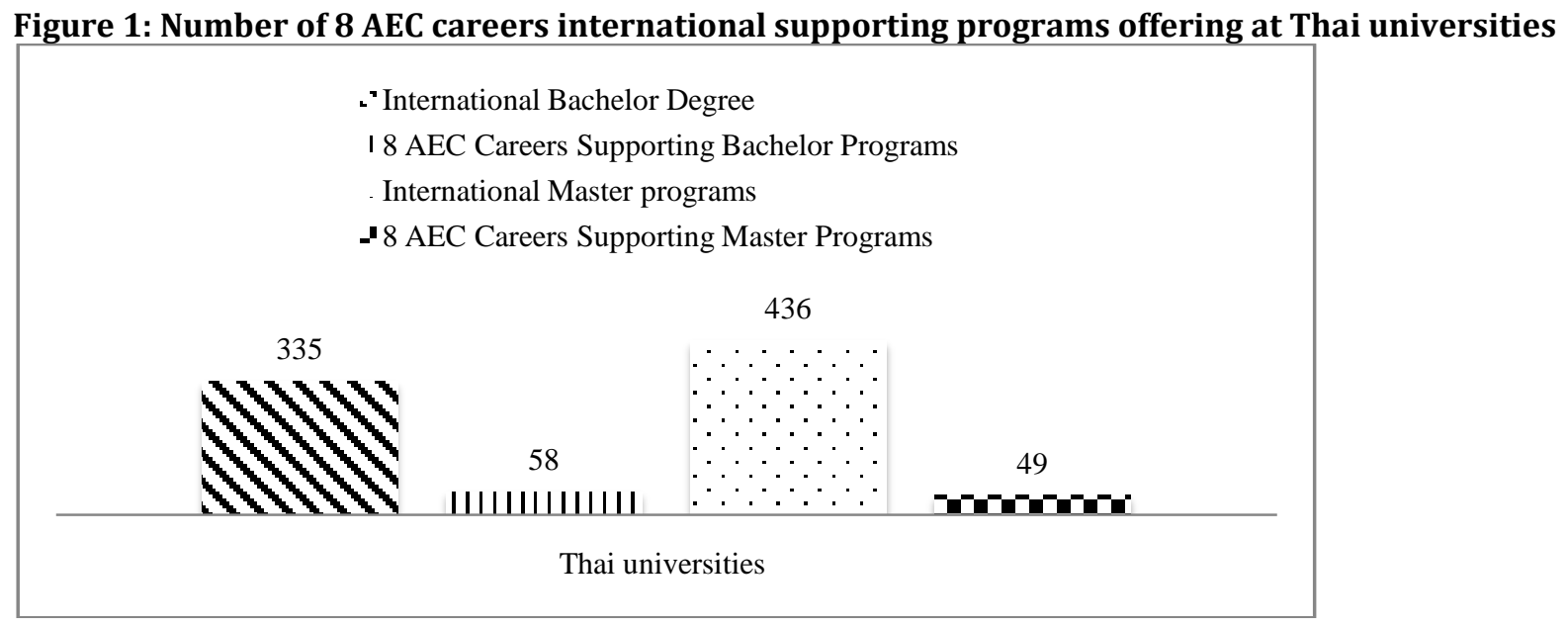

Figure 1 shows that Thai universities offer 335 international Bachelor programs while 436 international Master programs. Only 58 Bachelor and 49 Master programs are offered by English to support 8 AEC careers. 
Figure 2: Number of Thai Universities offering International Bachelor Degree programs among 8 careers for AEC

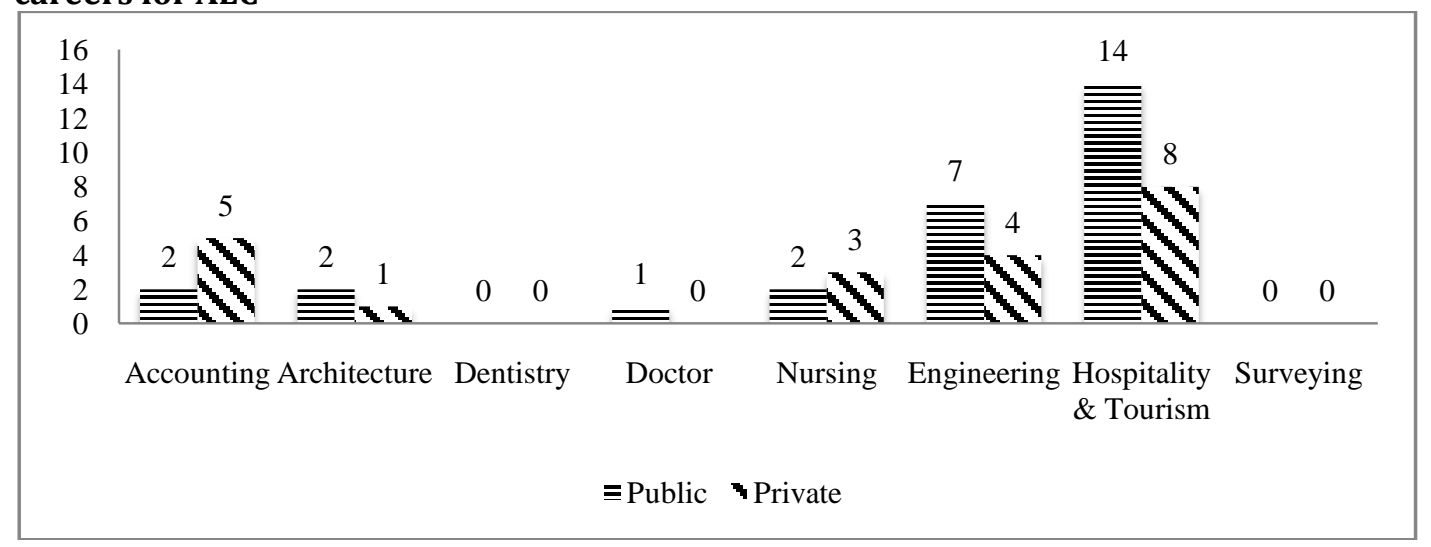

Figure 2 shows international Bachelor degrees that help towards 8 occupations for AEC. None of the public or private universities offers undergraduate international programs to support surveying and dentistry. But fourteen public and eight private universities offer hospitality \& tourism program. Three private universities offer nursing while two public universities offer it. Seven public universities offer engineering program while four private universities offer it. Only one public university offers medical practice (doctor) programs while no private university offers it at all. Two public universities and one private university offer architecture program. Furthermore, five private universities and two public universities offer accounting program.

Figure 3: Number of Thai Universities offering International Master Degree programs among 8 careers for AEC

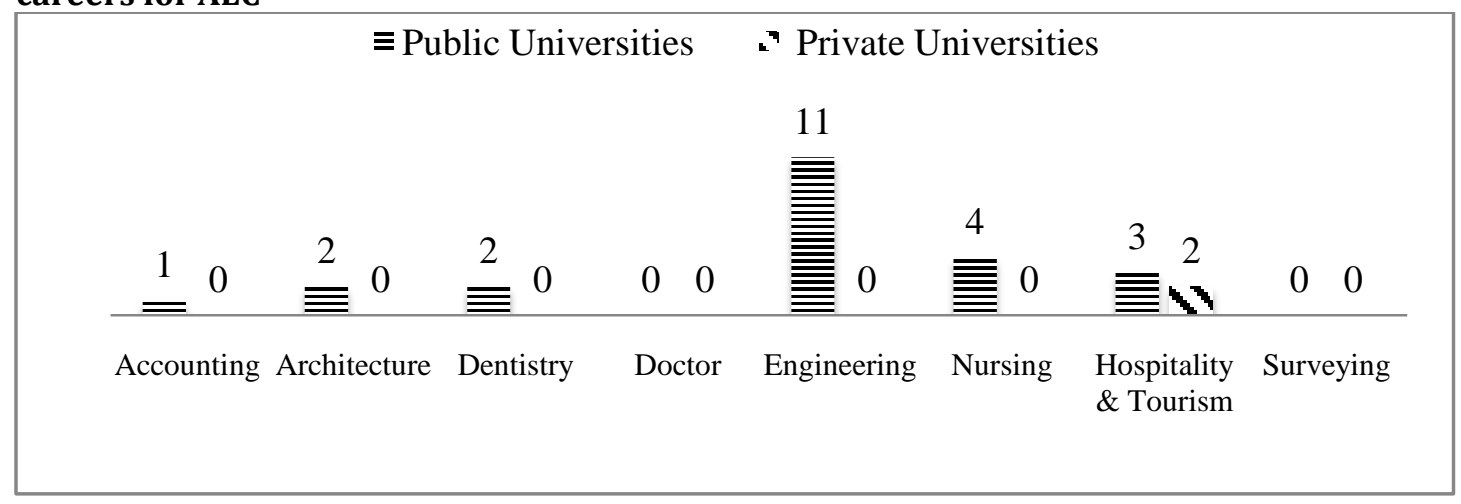

Figure 3 shows that none of the public or private universities offer undergraduate international programs to support surveying and meidical practice (doctor). Private institutions only 2 universities offer hospitality \& tourism program. 11 public universities offer engineering, while 4 universities offer nursing program. 3 universities offer hospitality \& tourism program, while 2 universities offer architecture and dentistry programs. Only 1 university offers Accounting program. Figure 3 indicates that private universities show less competitivenss on Master programs. They only offer two programs to support 8 AEC standard occupations. Public universities also offer a few programs. No surveying and doctor are offered by both public and private universities. Thai higher institutions do not cover all the 8 AEC standard occpations, and may not maxmize the AEC opportunities.

The details of 8 AEC careers offering by Thai universities in Bachelor are as follows: Thai universities offer two programs for accounting career : accounting, accounting and finance. Two programs are offered for architecture career: architecture, interior architecture. Seventeen programs are offered for engineering career, which include automotive design and manufacturing, chemical, civil, computer, electrical, environmental, industrial, information and communication, mechanical, nano-engineering, naval architecture 
and marine, software and knowledge and telecommunications and electronics engineering areas. One nursing science program is offered for nursing career. Twenty hospitality \& tourism programs are offered for hospitality \& tourism career, which include hotel, resort and restaurant management, hospitality and tourism industry, hospitality \& tourism management, intercultural studies for tourism. One doctor of medicine programs is offered for doctor career. Neither is dentistry nor surveying programs offered by Thai universities.

In terms of $8 \mathrm{AEC}$ career supporting programs, Thai universities only offer $17.31 \%$ programs at Bachelor level while they only offer $11.24 \%$ programs to support 8 AEC careers at Master level. Also, $86.49 \%$ and $76.19 \%$ international programs offered by public and private universities are only engineering and hospitality \& tourism programs. At Bachelor level, Thai higher undergraduate international education curriculums only cover six AEC careers: accounting, architecture, doctor, engineering, hospitality \& tourism, nursing, and focus only on hospitality \& tourism and engineering and accounting. At Master level, the findings show that Thai higher institutions only cover six AEC careers: accounting, architecture, dentistry, engineering, hospitality \& tourism, and nursing. Neither is Bachelor level nor Master level cover surveying program. The study clearly pointed that Thai higher institutions do not cover all the occupations. Mutual Recognition Agreements (MRAs) agreed on eight professions: engineering, nursing, physician, dental, architecture, surveying, accounting and hospitality \& tourism. The agreements between the 10 ASEAN member countries mean licensed and recognized professionals in these fields can move to other ASEAN countries to practice, but they are still subject to pass that country's licensing test. Thai universities, especially the private universities should pay more attention to offering more AEC supporting programs for Master levels. According to the findings of this study, it is obvious that Thai higher institutions are not really prepared to forth coming AEC on 2015. As The American Chamber of Commerce's ASEAN Economic Community Outlook pointed that,

"Thailand is aware that in order to improve competitiveness, it has to improve its capability in human capital through improving availability and quality of education, and fostering improvements in productivity and innovation. To do this, there needs to be more partnering between the government (e.g. Ministries of Education, Industry and Labor) with industry/employers in a productive dialogue on how to improve Thailand's competitiveness and raise standards of living at the same time. We are all stakeholders in the success of the country." (August 5, 2011).

Thai higher institutions offer very few AEC standard occupation-supporting programs and may not maximize AEC opportunity to provide specialist workforce. The article "Education Key to AEC Success" from Bangkok Post (27 April, 2012) reported, "Without education reform, the country cannot maximize AEC opportunity, any AEC benefit will be concentrated in the hands of the privileged few who are already well-equipped for change." 2015 is the last year for ASEAN Tourism Strategic Plan (2011-2015). One of the plans is to cultivate tourism related personnel for the development of cooperation, service and infrastructure. Unfortunately, the strategy about the tourism has not been fully understood with supporting resources, resulting in hotels, restaurants and tourism talents not being ready to gain achievements. In fact, Thailand's shortcomings in both quantity and quality of labor force make it hard to achieve the present goal (ASEAN newspaper, 19 March, 2015). In order to face those challenges, Thailand came up with a new education strategy plan to prepare for the ASEAN integration in terms of English proficiency, curriculum development, and teaching with international quality standard.

From the findings we can see that Thailand is not ready for the AEC. At the seminar "Is Thailand Ready for the AEC?" Finance Minister Sommai Phasee and key private-sector voices warned that the Kingdom has a long way to go before it is ready for the full implementation of the ASEAN Economic Community at the end of 2015 (The Nation, December 12, 2014). A report from Mathichon Newspaper said that, "Thai workforce lacks both quality and quantity to join the AEC market and it will have an impact on hotel business and tourism business. Thais may not be able to get more opportunities or benefits from AEC" (20 February, 2015, p10). 


\section{Conclusion}

The findings of an overview picture of Thai international 8 AEC careers supporting programs can be a guideline for universities to offer new programs to be well prepare a for the coming AEC free market. According to the results from other studies in the literature and the finding of this study, Thailand higher institutions need to offer more ESP programs especially the medicine practice, dentistry, nursing, land surveying and architecture related programs. Thailand is not ready for the forth coming AEC and still needs time to enhance the comprehensive qualities of international higher education. Thus, this study indicates that in order to gain competitiveness towards the AEC, Thailand urgently needs to improve its higher education.

Limitation of the study: The study analyzes the current 335 Bachelor international degree programs and 436 Master international degree programs in Thai higher institutions. The rest of the universities offer programs in Thai and so they are not included in this study. The author who wrote this paper is a Chinese graduate student and may not know the situations and policies of Thailand.

Policy Implications for AEC: For policy implication, Thailand government should promote the leadership role of higher education institutions in Thailand related to the three pillars of the ASEAN Community building, especially in the ASEAN Socio- Cultural Community pillar and develop the infrastructure development in international quality standard to support Thai local education to be a hub among ASEAN countries. For the Thai higher education, Thai higher institutions need to reform curriculum in those English programs to suit the AEC market needs. Thais do not have much competitiveness in medicine, dentistry, nursing, accounting and architecture, because Thai high institutions offer few of these programs. With no support on those careers, Thais will lose lots of opportunities to succeed in this field. Thai higher institutions need to strengthen the programs that are offered already and to make them more effective to meet the AEC market needs.

\section{References}

AEC Tourism Thai (2014). The website of AEC Tourism Thai, from http://en.aectourismthai.com/content1/1038.

AEC Tourism Thai (2014). The website of AEC Tourism Thai, from http://en.aectourismthai.com/content1/1435.

Aring, M. (2015). ASEAN Economic Community 2015 enhancing competitiveness and employability through skill development (No. 487273). International Labor Organization.

ASEAN Secretariat New. (2013). from http://www.asean.org/news/asean-secretariat-news/category/20132.

ASEAN Community. (2015). Managing integration for better jobs and shared prosperity, published by international labor organization, from: www.ilo.org/publns.

ASEAN Economic Community Blueprint. (2008). ASEAN Secretariat, Jakarta January 2008, from http://www.asean.org/archive/5187-10.pdf

ASEAN Curriculum Sourcebook. (2012). Retrieved: November 11, 2012, from: http://www.biotrop.org/attachments/ASEAN_Curriculum_Sourcebook.pdf

Bangkok Post News. (2015). from http: //www. bangkokpost.com/ news/asean/ 454399/long-road-stillahead-for-aec-services- liberalization.

Bangkok Post News. (2015). from http://www.bangkokpost.com/business/news/457351/leaders-neededfor-aec.

Bangkok Post News. (2015). from http://www.bangkokpost.com/business/tourism/455164/strong-pushfor-tourism-gains

Bangkok: Overview of Current Thai Higher Education Development. (2010). Retrieved August 20, 2010, from http://inter.mua.o.th/main2g /files/file/policy \&issue/OHEC\%20policy \%issueThai\%20higher\%20education\%20policyissue.pdf

Borneo Bulletin Online. (2015). Brunei will benefit from AEC 2015, March 25,2015from http://borneobulletin.com.bn/brunei-will-benefit- from-aec-2015/

Celce-Murcia, M. \& McIntosh, L. (1991). Teaching English as a second or foreign language (p. 244). Boston, MA: Heinle \& Heinle. 
CharasSuwanwela. (2013). Higher Education Reform in Thailand, Chulaongkorn University, Bangkok, Thailand, 2013.

Chang, C. T. (2004). Internationalization Development of Thailand's Higher Education: Positioning Thailand as an International Education Hub for the ASEAN Region. In SEAMEO-UNESCO Education Congress and Expo: Adapting to Changing Times and Needs, Bangkok (pp. 27-29).

Chien, C. L. \& Chapman, D. W. (2014). Graduate Education in Malaysia and Thailand. International Higher Education, (76), 20-22.

Choomnoom, S. (2011). Establishment of National Qualification Framework (NQF) and Planning for Manpower Production and Development according to NQF. (Presented at the International conference on implementation of National Qualifications Framework, April 27-28, 2011, Bangkok, Office of Education Council, Ministry of Education

Do, H. T. (2012). Governance Reform in Higher Education of Vietnam, from SEAMEO Regional Training Centre, Vietnam, 2012.

Indonesia Trade \& Export. (2015). Indonesia needs skilled workers to face AEC, Indonesia Trade \& Commodity Finance $\quad$ Conference $2015 . \quad$ April 23, from http://www.antaranews.com/en/news/93859/indonesia-needs-skilled-workers-to-face-aec

Juan, M. L. (2014). Is Philippine Higher Education ready for AEC, Asian Institute of Management, 25 September 2014 http://www.ilo.org/public/english/dialogue/actemp/ Is Philippine Higher Education ready for AEC.pdf

Lao PDR, published by Regional Environmental Technical Assistance 5771 Poverty Reduction \& Environmental Management in Remote Greater Mekong Subregion (GMS) Watersheds Project (Phase I).

Lack of Workforce for AEC market-Thailand is not ready for AEC at 2015? published by Mathichon, 20 February, 2015, p10.

Ministry of Education, Singapore, Report of the Committee on University Education Pathways Beyond 2015, August 2012.

Ministry of Labor, Employment and Social Security, Enhancing Skills Recognition Systems in ASEAN (20042008), 2014, from http://tvetmyanmar.org.

National Qualifications Framework for Higher Education in Thailand November 2006. http://www.mua.go.th/users/tqf-hed/news/FilesNews/FilesNews8/NQF-HEd.pdf

Report on Higher Education Internationalization Policy and Strategy, Office of the Higher Education Commission, Thailand. October 2015.

Schwab, K. (2010). The global competitiveness report 2010-2011. Geneva: World Economic Forum.

Study in Thailand. (2014). published by Office of the Higher Education Commission Thailand

Study in Thailand: International program in Thai higher education institutions (2006) published by Office of the Higher Education Commission Thailand.

Thai-Norwegian Chamber of Commerce, 2015, Why the AEC in 2015 will lead to Few Changes in Thailandhttp://www.norcham.com/news/why-the-aec-in-2015-will-lead-to-few-changes-in-Thailand.

The Ministry of Education Strategic Plan 2012- 2017, published by Strategic Management Unit Department of Planning, Development and Research Ministry of Education Brunei Darussalam 2012, from http://planipolis.iiep.unesco.org/upload/Brunei\%20Darussalam/Brunei_Darussalam_Strategic_Plan _Book_2012-2017.pdf

The Nation, ASEAN is not yet ready for integration, September 18, 2013, from http://www.nationmultimedia.com/national/Asean-is-not-yet-ready-for-integration-Mahathir-sa30215069.html.

The Nation, Thailand not ready for AEC, finance minister tells seminar, December 12, 2014 http://www.nationmultimedia.com/business/Thailand-not-ready-for-AEC-finance-minister-tells-30249635.html.

Zaaba, Z., Ibrahim-Ramadan, F., Gunggut, H., Chuah, B. L. \& Umemoto, K. (2011). Internationalization of higher education: a case study of policy adjustment strategy in Malaysia. International Journal for CrossDisciplinary Subjects in Education (IJCDSE), 1(1), 565-576. 